Kopec A., Are the new Polish tax rules regarding partnerships limited by shares in breach of EU law? Analysis of amendments to the Polish Income Tax Act 2014 in the light of ECJ case law, „Ekonomia i Prawo. Economics and Law", Polszakiewicz B., Boehlke J. (ed.), Vol. 14, No. 2/2015, pp. 205-219. DOI: http://dx.doi.org/10.12775/EiP.2015.012.

\title{
ARE THE NEW POLISH TAX RULES REGARDING PARTNERSHIPS LIMITED BY SHARES IN BREACH OF EU LAW? ANALYSIS OF AMENDMENTS TO THE POLISH INCOME TAX ACT 2014 IN THE LIGHT OF ECJ CASE LAW ${ }^{\diamond}$
}

\author{
SUMMARY
}

With effect from 1 January 2014, the Polish Parliament introduced amendments to the Polish Corporate and Personal Income Tax Acts, which primarily affect the taxation of a partnership limited by shares (SKA) by including it into the category of corporate income tax subjects. Under the new regulations the general partners of an SKA should be treated in the same way as partners of any other Polish partnership and thus their income should be effectively taxed only once. In order to ensure the single-level taxation of general partner's income a tax credit mechanism has been introduced. Though, the new Polish provisions permit the application of the tax credit mechanism only in relation to national cases. In the authors' view this may constitute a restriction on freedom of establishment. This article analyses whether the new tax credit method is compatible with EU Law.

Keywords: tax reform, partnership limited by shares, EU law compatibility, ECJ case law

JEL Classification: F15, H20, H24, H25

Agnieszka Kopec, European University Viadrina, Faculty of Business Administration and Economics, Chair of Business Taxation and Auditing, Große Scharrnstr. 59, 15230 Frankfurt (Oder), Germany, phone: +49(0) 335553426 20, e-mail: kopec@europa-uni.de.

$\checkmark$ The author thanks Stephan Kudert and Agata Nagel for their useful comments. 


\section{INTRODUCTION}

On 1 January 2014 amendments to the Corporate Income Tax Act (CITA) and Personal Income Tax Act (PITA) came into effect ${ }^{1}$. The main change involved new taxation rules for SKA (spótka komandytowo-akcyjna). Pursuant to the new tax rules the general partners of an SKA are allowed to credit the part of the CIT paid by an SKA, which is proportional to their share of profit against withholding tax imposed on their dividends. However, the tax credit method is available only for domestic CIT. This article provides a detailed analysis on the basis of European Court of Justice (ECJ) case law of whether the new Polish tax rules regarding the tax credit method are in line with EU Law.

\section{OVERVIEW OF THE NEW POLISH TAX CREDIT METHOD}

Since 1 January 2014 an SKA has been considered a taxable person ${ }^{2}$. Consequently, the income of an SKA is basically taxed twice: first at the level of the partnership (19.0\% CIT), second if a dividend is distributed to the partners $\left(19.0 \%\right.$ withholding $\operatorname{tax}^{3}$ ). The double taxation generally occurs if the recipient of dividend payment is SKA's shareholder ${ }^{4}$. However, according to the new tax regulations ${ }^{5}$, the general partner is entitled to credit against the withholding tax that part of the underlying CIT levied on the income generated by an SKA, which is proportional to his interest in the partnership and is attributable to the distributed earnings ${ }^{6}$. The tax credit mech-

${ }_{1}$ Ustawa z dnia 8 listopada 2013 r. o zmianie ustawy o podatku dochodowym od osób prawnych, ustawy o podatku dochodowym od osób fizycznych oraz ustawy o podatku tonażowym (Corporate Income Tax and Personal Income Tax Ammendent Act of November 8, 2013), Dz.U., No. 8, item 1387.

2 Ibidem, art. 1(3) No. 1.

3 Ibidem, art. 22(1) or art. 30a(1).

${ }^{4}$ Profits distributed to corporate shareholders stated in Poland or in another EU or EEA Member State are generally exempt from the withholding tax due to ibidem, art. 22(4). For non-resident individuals or corporate shareholders from outside EU and EEA countries, a reduction of the WHT rate due to the terms of an applicable tax treaty may apply.

5 Ibidem, art. 22(1a) and Art. 30a(6a).

${ }^{6}$ Ibidem, art. 22(1a)-(1e) and art. 30a(6a)-(6e). The tax credit is limited and cannot exceed the amount of withholding tax payable on the dividend distribution. See ibidem, art. 22(1b) and art. $30 \mathrm{a}(6 \mathrm{~b})$. 
anism should ensure that the general partner is not double taxed ${ }^{7}$. Hence, because of his status as an active, fully liable investor under company law, there should be no difference in the effective tax burden of income attributable to him in comparison to the partners of other tax-transparent partnerships ${ }^{8}$ being taxed only once.

If an SKA generates its profit only from Polish sources being pretaxed with Polish CIT, the full tax credit is granted. Thus, the aim made by the Government to ensure single-level taxation of general partner's income is achieved ${ }^{9}$. It is, however, questionable whether foreign tax imposed on SKA's income can be credited against the withholding tax paid by the general partner.

Example: In 2014 the SKA generates income of 100 PLN from a permanent establishment (PA) located in an OECD-Country. Under Art. 7(1) of the OECD Model Tax Convention ${ }^{10}$ (OECD-MTC), business profits attributed to a PA in another Contracting State should be taxed at the place of its location. Assuming CIT rate abroad is similar to Poland (19.0\%), the total tax burden in the foreign country would amount to 19 PLN.

Business profits attributed to a foreign PA are tax-exempt in a country of residence of the SKA (Art. 23A OECD-MTC). Accordingly, if we assume that the SKA does not generate any profit in 2014 and its income stems only from the PA, no Polish CIT will be due in 2014. In 2015 the dividend of 81 PLN is paid out. The company is obliged to impose withholding tax on the dividend of $19.0 \%(81 \mathrm{PLN} * 0.19=15.39 \mathrm{PLN})$. If the general partner is the beneficiary of the dividend, the tax credit method provided in Art. 22(1c) of CITA applies.

However, under the new regulations, only CIT imposed on taxable income in Poland can be credited against the withholding tax on a general partner's dividend. Since income from an SKA attributable to a PA abroad is taxexempt in Poland, no tax credit is allowed to the general partner ${ }^{11}$. A specific

${ }^{7}$ Explanatory memorandum of the Polish Government to the Draft Bill of September 17, 2013, art. 30-31.

${ }^{8}$ Other types of commercial partnerships in Poland are: general partnership, professional partnership and limited partnership.

${ }^{9}$ For more detailed description of the tax reform see S. Kudert, A. Kopec, Die Besteuerung der polnischen KGaA im Lichte der Steuerreform 2014: Gesetzesziele, Vorgehensweise und Regelungsdefizite, „RIW”, Vol. 5/2014, pp. 272-280.

10 OECD, Model Tax Convention on Income and on Capital 2010.

11 According to Ustawa $z$ dnia 8 listopada 2013 r..., op. cit., art. 30a(6a) or Art. 22(1a) the amount of CIT that can be deducted from withholding tax on dividend has to be calculated pursuant to art. 19, 18 and 7. Art. 7(3) No. 1 states that income generated abroad, which was not subject to Polish CIT cannot be considered for deduction. 
rule regarding foreign tax credit has been introduced neither into the Polish CITA nor PITA. As a result, an SKA's foreign profit, which is distributed as a dividend to a general partner, is effectively taxed twice (total tax burden: 34.39 PLN). Though, double taxation does not take place if the dividends paid by an SKA stem from the Polish source of income (tax burden: 19 PLN). For this reason, the Polish new tax regulations could be seen as restrictive for the general partner of an SKA and therefore contrary to EU Law.

Table 1. The SKA earns income through PA abroad or through PA in Poland

\begin{tabular}{|c|c|c|}
\hline SPECIFICATION & PA IN OECD-COUNTRY & PA IN POLAND \\
\hline CIT in OECD-State & 19.00 & 0.00 \\
\hline CIT PL & 0.00 & 19.00 \\
\hline Dividend & 81.00 & 81.00 \\
\hline WHT (19.0\% of the dividend) & 15.39 & 15.39 \\
\hline Tax credit & 0.00 & $15.39^{*}$ \\
Total tax & 34.39 & 19.00 \\
\hline
\end{tabular}

See footnote No. 6.

Source: Own preparation.

\section{THE CURRENT STATE OF KNOWLEDGE AND THE METHODOLOGY OF RESEARCH}

An SKA is a relative new legal form in Poland. Therefore the volume of literature in this research area is narrow. The existing literature in the field of taxation of SKA's profits is limited to a couple of practical and academic papers, which mainly analyse the tax consequences of the investment carried out in the legal form of SKA. With regard to the old legal framework dominated before the tax reform 2014 the articles of Golec ${ }^{12}$ and Jamroży ${ }^{13}$ in Polish, Pankiewicz ${ }^{14}$ in English and Kopec and Nagel ${ }^{15}$ in German are worth mentioning. The new tax regulations for Polish SKA, however, are criti-

12 S. Golec, Opodatkowanie podatkiem dochodowym akcjonariuszy spótek komandytowo-akcyjnych — zagadnienia problemowe, „Przegląd Podatkowy”, No. 6/2012.

${ }^{13}$ M. Jamroży, Spótka komandytowo-akcyjna jako podatkowy webikut inwestycyjny, [in:] R. Bartkowiak, J. Ostaszewski (ed.), Dorobek ekonomii, finansów i nauk o zarzqdzaniu oraz jego praktyczne wykorzystanie na przetomie XX i XXI wieku, Szkoła Główna Handlowa - Oficyna Wydawnicza, Warszawa 2012.

${ }_{14}$ P. Pankiewicz, Ambiguous income tax regulation reveals preferential tax regime in Poland, „European Taxation”, Vol. 53, No. 1/2013.

15 A. Kopec, A. Nagel, Polnische KGaA als steuerliches Gestaltungsinstrument deutscher Investoren: Von Irrungen und Wirrungen und der Zukunft eines Investitionsvehikels, „IStR“, No. 24/2013. 
cally discussed by Kudert, Kopec, Nage ${ }^{16}$ and Stiller ${ }^{17}$. Both of the abovementioned publications concern the functioning of the amended tax provisions regarding an SKA, in particular with reference to the taxation of a general partner's profit. The review of the literature shows that there is no evidence provided the analysis whether the new tax provisions are compatible with the EU Law. The present study aims to fulfil this "research gap" and to examine whether the new tax regulations could be seen as contrary to the fundamental freedoms safeguarded in the EU Treaties.

Methodically the following article can be allocated to the Business Tax Law. Based on ECJ case law, this study provides a detailed analysis of the conformity with EU Law and can be seen as some art of tax law criticism.

\section{THE RESEARCH PROCESS: DOES THE NEW TAX CREDIT SYSTEM IN POLAND BREACH EU LAW?}

\subsection{INTRODUCTORY REMARKS}

The Polish tax system has undergone substantial changes since the early 1990s. Most of the amendments adjusting Polish Income Tax Law to EU Law came into force as of May 1, 2004 and were required due to Poland's accession to the $\mathrm{EU}^{18}$. Because of the fact that EU Law is superior to national law, Polish tax authorities and courts are not only obliged to apply the EU Law being implemented into domestic legal provisions. According to the precedence principle ${ }^{19}$, Poland as a Member State must set aside national tax regulations in the case they contradict to $\mathrm{EU} \mathrm{Law}^{20}$. With regard to primary law the fundamental freedoms laid down in Art. 26(2) of the TFEU ${ }^{21}$ that aim to guarantee equal treatment of comparable domestic and cross-border situ-

16 S. Kudert, A. Kopec, A. Nagel, Poland: 2014 Income Tax Law Changes: New Taxation Rules for Partnerships Limited by Shares, „European Taxation”, Vol. 55, No. 1/2015.

${ }_{17} \mathrm{~W}$. Stiller, How to tax partnerships limited by shares, "Journal of Economics \& Management", Vol. 18/2014.

${ }_{18}$ T. Wołowiec, J. Soboń, EU Integration and Harmonisation of Personal Income Taxation, „Contemporary Economics”, Vol. 5, No. 1/2011, p. 36.

${ }^{19}$ To ex officio application of EC Law by national tax courts see e.g. A. Eijsden, J. Dam, The Impact of European Law on Domestic Procedural Tax Law: Wrongfully Underestimated?, „EC Tax Review", Vol. 19, No. 5/2010, p. 207.

20 ECJ Case No. C-26/62, Van GendELLoos, 5 February 1963, ECR 1963 and ECJ Case No. C-6/64, Costa/E.N.E.L., 15 June 1964, ECR 585. See also: M.C. Barreiro Carril, National Tax Sovereignty and EC Fundamental Freedoms: The Impact of Tax Obstacles on the Internal Market, „Intertax”, Vol. 39, No. 2/2010, p. 105.

21 Treaty on the Functioning of the European Union of October 26, 2012, Dz.U. C 326. 
ations are relevant. In connection to the above, imposing a higher tax burden on the income of a general partner of an SKA attributable to an economic activity abroad may constitute discrimination and could be therefore declared contrary to the fundamental freedoms ensured by primary EU Law. This question will be analysed below.

\subsection{RESTRICTION OF THE FUNDAMENTAL FREEDOMS}

\subsubsection{Cross-border character}

First of all, it has to be examined whether the discussed issue falls within the scope of EU Law and does not concern a purely internal matter ${ }^{22}$. This question arises mostly due to the fact that the general partner of an SKA being potentially restricted by Polish tax provisions does not make use of his own right of free movement laid down by the Treaty's fundamental freedoms. Not he but the SKA moves abroad to set up a branch in another Member State. On the other hand, it has to be noted that the refusal of application of the tax credit method does not affect the SKA's tax burden, but only the total tax amount imposed on the general partner's level. The question arises whether the fact that the dividend attributable to the foreign income and distributed to the general partner of an SKA is sufficient to consider a cross-border situation.

In the case Shempp $p^{23}$ the ECJ found out that the situation of the nationals of the Member State, who have not made use of their own right to freedom of movement cannot be identified as a purely internal situation. In the mentioned case, the taxpayer - Mr. Shempp - relies on the fundamental freedom, which has not been exercised by himself, but by his former spouse. The ECJ pointed out that the exercise of free movement rights by the applicant's former spouse creates a sufficient link with the EU Law because it directly affects his tax situation. ECJ referred to its earlier judgment in case $C_{h e n}{ }^{24}$, where it confirmed that the right to claim the benefits

${ }^{22}$ According to the case law of ECJ, the cross-border character of the situation is a condition for application of fundamental freedoms. See ECJ Case No. C-332/90, Steen, 28 January 1992, ECR I-341, para. 9; ECJ Joined Cases No. C-419/12 and C-420/12, Crono Service, 13 February 2014, para. 37. See A. Tryfonidou, Reverse discrimination in purely internal situations: an incongruity in a citizens' Europe, „Legal Issue of Economic Integration”, Vol. 35, No. 1/2008, p. 46.

${ }^{23}$ ECJ Case No. C-403/03, Schempp, 12 July 2005, ECR I-6421, paras 22-25.

${ }^{24}$ ECJ Case No. C-200/02, Chen, 19 October 2004 , ECR I-9925, para. 19. 
of the Treaties can be derived from the right of free movement of other persons ${ }^{25}$.

Similar to the case of $M r$. Schempp, the rights and obligations of the general partner are also affected by another subject making use from the EU fundamental freedoms. The fact that an SKA exercises its right to move to another Member State influences the possibility of the general partner to deduct the foreign CIT from withholding tax imposed on dividend distribution. Consequently, although the general partner does not make use from his own right of free movement, he can derive the possibility to rely on EU Law from the fact that his tax position is directly affected by the SKA doing business abroad. Thus, no purely internal situation is applicable and the general partner's right to claim the benefits of EU Law cannot be excluded.

\subsubsection{Application of freedom of establishment}

In order to examine whether the Polish tax rules in question constitutes a breach of EU Law, the fundamental freedom applicable in this case should be determined. Art. 30a(6a) of PITA and Art. 22(1a) of CITA denying the application of tax imputation method in cross-border situations may fall under the freedom of establishment stated in Art. 49 of the TFEU and/ or freedom of free movement of capital laid down in Art. $63 \mathrm{TFEU}^{26}$.

Following the "dominance rule" developed by ECJ, if a national measure restricts two or more fundamental freedoms, the Court will examine the case in relation to only one of those freedoms, namely the predominant freedom that is closer related to the circumstances of the case ${ }^{27}$. The applica-

${ }_{25}$ C. Panayi, The Schempp case: a new leaf in the jurisprudence of the Court of Justice or just a fig leaf?, „European Taxation“, Vol. 45, No. 11/2005, p. 484; N. Bammens, The principle of nondiscrimination in International and European Tax Law, IBFD Doctoral Series, Vol. 24/2012, p. 1071 or J. Oberrath, Vereinbarkeit deutscher Steuervorschriften mit Gemeinschaftsrecht, "JA" Vol. 2006, p. 261.

${ }_{26}$ Because the maintenance of branch requires stable and continuous economic activity, the principle of the freedom to provide services does not apply, ECJ, Case No. C-357/10, Duomo Gpa, 10 May 2012. See also E. Kaldellis, Freedom of Establishment versus Freedom to Provide Services: An Evalu-ation of Case-law Developments in the Areas of Indistinctly Applicable Rules, „Legal Issues of Economic Integration“, Vol. 1/2001, pp. 23-55; F. Capriglione, Freedom of Establishment and Provision of Services, „European Business Law Review“, Vol. 33, No. 3/2004, pp. 447-461.

27 ECJ Case No. C-390/99, Canal Satelite Digital, 22 January 2002, ECR I-607, para. 31; ECJ Case No. C-196/04, Cadbury Schweppes, 12 Sepember 2006, ECR I-7995, para. 33. See also S. Hemels et al., Freedom of Establishment or Free Movement of Capital: Is There an Order of Priority? Conflicting Visions of National Courts and the ECJ, „EC Tax 
tion of freedom of establishment can be supported by the fact that an SKA pursues its economic activity through the PA located in another Member State and makes use from the secondary establishment. However, the discriminated party is not an SKA, but its general partner, whose right to impose the foreign CIT on the dividend payment is refused by Polish tax rules. By reference to the dividend distribution made by an SKA to the general partner, the case could be approached from the angle of freedom of free movement of capital, too. Therefore, it is not clear which fundamental freedom should be accessed in this case.

In the referring case $S$ chempp, the Court assessed the infringement of EU Law by examining the primary applicable fundamental freedom, i.e. the freedom, which Mr. Schempp's spouse has exercised (Art. 18 TFEU) ${ }^{28}$. By following the reasoning of ECJ in judgment Schempp the fundamental freedom relevant in the present case would be the freedom of establishment, on which the SKA relies. For this reason, it seems plausible that the Polish tax provisions should only be examined in the light of this freedom, i.e. Art. 49 and 54 of the TFEU, and that the independent examination of the breach of the free movement of capital should not be carried out.

\subsubsection{Restriction on freedom of establishment}

In order to ascertain whether national tax provisions are discriminatory or restrictive, we can apply a comparison test that the $\mathrm{ECJ}^{29}$ has developed in its judgements. For this purpose the aim pursued by the national provisions must be taken into consideration ${ }^{30}$. As explained in section 1 the intention of the Polish tax legislator was to eliminate double taxation on the profits distributed to general partners of an SKA. This purpose is achieved if the general partner receives a dividend from an SKA that generates part of its income attributable to a PA located in Poland. In this case he is entitled to tax credit pursuant to Polish Tax Law. The same situation, however, may incur an additional tax burden if the earnings of an SKA are attributed to a foreign PA.

Under the current ECJ case law, tax provisions trigger discrimination if their application leads to a different tax treatment in comparable situations.

Review“, Vol. 19, No. 1/2010, p. 21.; J. English, Taxation of Cross-Border Dividends and EC Fundamental Freedoms, „Intertax”, Vol. 38, No. 4/ 2010, p. 197.

${ }_{28}$ See footnote No. 18 and ECJ Case No. C-403/03, op. cit.

${ }^{29}$ ECJ Case No. C-80/94, Wielockx, 11 August 1995, ECR I-2493.

${ }^{30}$ ECJ Case No. C-39/13, SCA Group Holding, 12 June 2014, para. 28; ECJ Case No. C-80/12, Felixstowe Dock and Railway Company, 1 April 2014, para. 25. 
The ECJ has already issued several judgements in cases concerning tax benefits such as methods of avoiding double taxation in cross-border context.

In the Verkooijen case for example, the Court required the Netherlands to exempt inbound dividends from taxation in the same way that Dutch-sourced dividends were exempt ${ }^{31}$. The ECJ held that the provision which refuses tax deduction if dividend payment was done by a foreign company constituted an obstacle to raising capital in the Netherlands. This was because the dividends, which such companies paid to residents received less favourable tax treatment than dividends distributed by a company established in the Netherlands.

In the Manninen case, the ECJ considered the Finnish imputation system to be in breach with the free movement of capital since it was available for dividends from domestic companies paid to persons fully taxable in Finland, but not for dividends distributed by non-resident companies ${ }^{32}$. The Court noted that the tax credit under Finnish tax law is designed to prevent the double taxation of company profits distributed to shareholders. The goal of eliminating double taxation should be achieved not only by granting credits for CIT paid to Finland, but also for CIT paid to other Member States ${ }^{33}$.

There is also extensive case law of the ECJ in matters dealing with tax restrictions of freedom of establishment from the perspective of the state of origin that do not concern explicitly methods of avoiding double taxation.

In the Bosa ${ }^{\beta 4}$ judgement, for example, the ECJ ruled that the Dutch tax provisions, which denied the deduction for expenses relating to participations in foreign subsidiaries, violated the freedom of establishment. Under the controversial tax rules, expenses with respect to the loan were deductible only if the loan was related to a Dutch subsidiary. The tax deduction was denied if the relevant subsidiary made its profits being subject to tax in other Member State than Netherlands. According to the ECJ, national provisions, which make the deductibility of tax expenses subject to the condition that such costs are indirectly instrumental in making profits taxable in domestic country, are in breach of EU Law ${ }^{35}$.

31 ECJ Case No. C-35/98, Verkooijen, 6 June 2006, ECR I-4071.

32 ECJ Case No. C-319/02, Manninen, 7 September 2004, ECR I-747, para. 6.

33 See footnote No. 27; Ibidem, para. 20; G. Genta, Dividends Received by Investment Funds: An EU Law Perspective - Part 2, „European Taxation”, Vol. 53, No. 4/2013, p. 141.

${ }^{34}$ ECJ Case No. C-168/01, Bosal, 18 September 2003, ECR I-9409.

35 See also H. Hurk, B. Wagenaar, The Far-Reaching Consequences of the ECJ Decision in Bosal and the Response of the Netherlands, „BIFD “, Vol. 58, No. 6/2004, p. 269. 
In another case Argenta Spaarbank ${ }^{36}$ the Court considered the Belgian national interest deduction rules to be contrary to the freedom of establishment. The Court pointed out that taking into account assets of a PA in order to calculate the deduction for risk capital of a company subject to CIT in Belgium constitutes a tax advantage. Such a tax advantage was denied when the PA of the company resident in Belgium was situated in another Member State and the income attributable to it was tax-exempt in Belgium.

The ECJ cases described above are largely comparable to that of the Polish case with regard to one main aspect: The grant of certain tax advantages was denied to foreign income delivered to nationals that was pre-taxed by foreign CIT and was not taxable in domestic country. The same situation exists in the case of a Polish SKA's profits generated abroad. Under the new Polish tax provisions, foreign CIT paid in the Member State of the PA cannot be credited against withholding tax imposed on the share of profit of the SKA's general partner. Consequently, profits from abroad are disadvantaged in comparison to those that have been generated in the home country. As the Court highlighted in its judgements, such refusal of tax benefits in a cross-border situation leads to a different treatment in comparison to a domestic case. This may imply that the new Polish legislation constitutes a restriction on fundamental freedoms and therefore might be seen as contrary to EU Law.

\subsubsection{Possible justification for restriction}

Assuming that the current Polish tax credit provisions constitute a restriction on freedom of establishment, it becomes necessary to assess whether the rules could be justified under EU Law. Following the ECJ case law a restriction is permissible only if it pursues a legitimate objective compatible with the TFEU and is justified by imperative reasons in the public interest ${ }^{37}$.

The Polish Government stated in the Draft Bill that one of the primary aims of the new rules concerning the credit method was to prevent tax avoidance $^{38}$. The ECJ confirmed in its previous judgements that restriction on freedom of establishment could be justified as a measure against tax avoidance. According to the ECJ judgements, national tax rules must apply to wholly artificial arrangements with the goal of avoiding the tax normally due in or-

${ }^{36}$ ECJ Case No. C-315/11, Argenta Spaarbank NV, 4 Jule 2013. See also R. Neyt, S. Neeters, Balanced Allocation and Coherence: Some Thoughts in Light of Argenta and K, „EC Tax Review”, Vol. 23, No. 2/2014, pp. 64-75.

37 ECJ Cases No. C-451/05, ELISA, 11 October 2007, ECR I-8251, para. 79; ECJ Case No. C-152/05, European Commission v Germany, 17 January 2008, ECR I-39, para. 26.

${ }^{38}$ Explanatory memorandum..., op. cit., art. 8. 
der to be justified ${ }^{39}$. The Court emphasized that such arrangements should be designed to obtain a tax advantage and do not refer to the conduct of real business activity ${ }^{40}$. In the $I C I$ case the ECJ noted that the establishment of a company or a branch in another Member State does not itself necessarily entail tax avoidance, in particular if this company is subject to the tax legislation of the state where it is established ${ }^{41}$. The ECJ judgements indicate that the maintance of foreign PA including not-artificial arrangements cannot be justified on the ground of preventing tax abuse.

One may argue that the new Polish tax provisions were incorporated to ensure the maintenance of the coherence of the Polish fiscal system ${ }^{42}$. However, according to settled ECJ case law, in order for a national restrictive rule to be justified by this ground, there must be a link between the grant of a tax advantage and offsetting that advantage by a fiscal levy ${ }^{43}$. While analysing the cohesion argument, the ECJ used to consider the objective pursued by the legislation in the process of designating a new law provision ${ }^{44}$. In the case of the Polish SKA this was prevention of double taxation. With regard to the reasoning of the Court presented in the case Manninen, there is a risk of double taxation not only in the pure domestic case but also if the cross-border situation applies ${ }^{45}$. Therefore, the aim of eliminating double taxation should be achieved by granting the general partner of an SKA a tax credit calculated by reference to the foreign CIT paid on the profits, from which the dividend originated.

The ECJ has also accepted the need to safeguard the balance in taxing income as the justification for tax treatment that restricts the TFEU's freedoms $^{46}$. In the case of the Polish SKA the balanced allocation is safeguard

39 See footnote No. 22; ECJ Case No. C-196/04, op. cit, para. 51; ECJ Case No. C-524/04, Test Claimants in the Thin Cap GLO, 13 March 2007, ECR I-2157, para. 74.

${ }^{40}$ See footnote No. 34; Ibidem, paras 72 and 74; ECJ Case No. C-182/08, Glaxo Wellcome, 17 September 2009, ECR I-8591, para. 89.

41 ECJ Case No. C-48/69, ICI v Commission, 17 July 1972, ECR 619, para. 26. See T. O'Shea, Tax avoidance and abuse of EU Law, „EC Tax Journal”, Vol. 11/2010, p. 101.

42 ECJ Case No. C-204/90, Bachmann, 28 January 1991, ECR I-249; ECJ Case No. C-157/07, Krankenheim Ruhesitz, 23 October 2010, ECR I-8061, para. 43; ECJ Case No. C-375/12, Bouanich, 13 March 2014. See also F. Vanistendael, Cohesion: The phoenix rises from the ashes, „EC Tax Review”, Vol. 4/2005, pp. 208-222.

${ }^{43}$ ECJ Cases No. C-242/03, Weidert/Paulus, 15 July 2004, ECR I-7391, para. 25; ECJ Case No. C-35/98, op. cit.

${ }^{44}$ See footnote No. 27; ECJ Case No. C-319/02, op. cit., para. 29; ECJ Case No. C-39/13, op. cit.; ECJ Case No. C-40/13 and C-41/13, 12 June 2014, para. 28.

45 See footnote No. 27; ECJ Case No. C-319/02, op. cit., para. 35.

${ }^{46}$ See ECJ Cases No. C-337/08, X Holding, ECR I-1215, para. 29; ECJ Cases No. C-48/13, Nordea Bank, 17 July 2014, paras 31 subs.. See footnote No. 37; ECJ Case No. C-375/12, op. 
by the provisions of a double tax treaty, according to which an SKA's income from a foreign PA is taxed by the source state, where its registered seat is located. Granting foreign tax credit method to the general partner cannot form an obstacle to the balanced allocation of taxing rights between Poland and other Member States. This is because it does not affect either the taxation level of an SKA or the taxation of PA but only refers to the person of general partner who does not make use of his own fundamental freedom. Furthermore, the intention of Polish legislation was to eliminate double taxation on the profits distributed to general partners by ensuring one-level taxation. The risk of double taxation exists in respect of domestic as well as foreign-sourced dividends. Consequently, this justification ground is not longer valid if the Member State decided not to tax comparable domestic situation ${ }^{47}$.

\section{THE RESULTS OF RESEARCH}

The previous considerations have shown that no grounds for justifying the different tax treatment of income realized in an SKA's resident country in comparison to that generated in another Member State may be found. Therefore, it may be stated that the freedom of establishment precludes the provisions of Polish tax law which refuse the application of the tax credit relating to foreign tax imposed on income generated by an SKA in another Member State ${ }^{48}$. Accordingly, the general partner should be entitled to imputation credit on the dividends, even if the dividends have not been pretaxed with Polish CIT. The Polish imputation rule should apply analogously in granting cross-border tax credits.

In order to find out whether the Polish provisions infringe primary EU Law, the Polish administrative court may ${ }^{49}$ ask the ECJ for a preliminary ruling (Art. 267 of the TFEU). Further, to the preliminary reference the EU

cit., paras. 75 subs. See also L. Broe, The ECJ's Judgment in Argenta: Narrow Interpretation of 'The Preservation of the Balanced Allocation of Taxing Rights between Member States.'A Headache for Designers of Tax Incentives in the Union, „EC Tax Review“, Vol. 22, No. 5/2013, pp. 200-211.

47 ECJ Case No. C-284/09, European Commission v. Germany, 20 October 2010.

${ }^{48}$ Because EU Law applies not only at the Member State level, but also with regard to Member States' nationals that can invoke the incompatibility of the Polish tax provisions with EU Law before national courts and tribunals do this. See supra n. 15, ECJ Case No. C-26/62, op. cit., para. 3 .

${ }^{49}$ If any such question is raised in a case pending before a court or tribunal of a Member State against whom decisions there is no judicial remedy under national law, that court or tribunal must bring the matter before the ECJ. See Treaty on the Functioning of the European Union, op. cit., art. 267(3). In Poland the court of last instance in administrative cases is the SAC. 
Commission may start an infringement procedure against the Member State if it considers the Member State's legislation hypothetically may breach EU Law (Art. 258 of the TFEU).

\section{CONCLUSIONS}

An analysis of the compatibility of the Polish tax legislation with EU Law on the basis of the reasoning used by the ECJ in its judgements shows that the new tax regulations regarding taxation of an SKA's general partner's profit leads to a different treatment of cross-border cases in comparison to domestic situations and therefore may imply a restriction on freedom of establishment. Taking into consideration the wide scope of the ECJ's judgements, it seems doubtful whether the controversial Polish tax credit rules could be justified as in line with the fundamental freedoms of the EU. Thus, in the authors view, the Polish tax approach leads to legal uncertainty that could only be reduced if the ECJ examines the new tax provisions.

\section{BIBLIOGRAPHY}

Bammens N., The principle of non-discrimination in International and European Tax Law, IBFD Doctoral Series, Vol. 24/2012.

Barreiro Carril M.C., National Tax Sovereignty and EC Fundamental Freedoms: The Impact of Tax Obstacles on the Internal Market, „Intertax”, Vol. 39, No. 2/2010.

Broe L., The ECJ's Judgment in Argenta: Narrow Interpretation of 'The Preservation of the Balanced Allocation of Taxing Rights between Member States'. A Headache for Designers of Tax Incentives in the Union, „EC Tax Review“, Vol. 22, No. 5/2013.

Capriglione F., Freedom of Establishment and Provision of Services, „European Busi-ness Law Review“, Vol. 33, No. 3/2004.

ECJ Case No. C-152/05, European Commission v Germany, 17 January 2008, ECR I-39.

ECJ Case No. C-157/07, Krankenheim Ruhesitz, 23 October 2010, ECR I-8061.

ECJ Case No. C-168/01, Bosal, 18 September 2003, ECR I-9409.

ECJ Case No. C-182/08, Glaxo Wellcome, 17 September 2009, ECR I-8591.

ECJ Case No. C-196/04, Cadbury Schweppes, 12 Sepember 2006, ECR I-7995.

ECJ Case No. C-200/02, Chen, 19 October 2004 , ECR I-9925.

ECJ Case No. C-204/90, Bachmann, 28 January 1991, ECR I-249.

ECJ Case No. C-26/62, Van GendE'Loos, 5 February 1963, ECR 1963.

ECJ Case No. C-284/09, European Commission v. Germany, 20 October 2010.

ECJ Case No. C-315/11, Argenta Spaarbank NV, 4 Jule 2013.

ECJ Case No. C-319/02, Manninen, 7 September 2004, ECR I-747. 
ECJ Case No. C-332/90, Steen, 28 January 1992, ECR I-341.

ECJ Case No. C-35/98, Verkooijen, 6 June 2006, ECR I-4071.

ECJ Case No. C-375/12, Bouanich, 13 March 2014.

ECJ Case No. C-39/13, SCA Group Holding, 12 June 2014.

ECJ Case No. C-390/99, Canal Satelite Digital, 22 January 2002, ECR I-607.

ECJ Case No. C-403/03, Schempp, 12 July 2005, ECR I-6421.

ECJ Case No. C-48/69, ICI v Commission, 17 July 1972, ECR 619.

ECJ Case No. C-524/04, Test Claimants in the Thin Cap GLO, 13 March 2007, ECR I-2157.

ECJ Case No. C-6/64, Costa/E.N.E.L., 15 June 1964, ECR 585.

ECJ Case No. C-80/12, Felixstowe Dock and Railway Company, 1 April 2014.

ECJ Case No. C-80/94, Wielockx, 11 August 1995, ECR I-2493.

ECJ Cases No. C-242/03, Weidert/Paulus, 15 July 2004, ECR I-7391.

ECJ Cases No. C-337/08, X Holding, ECR I-1215.

ECJ Cases No. C-451/05, ELISA, 11 October 2007, ECR I-8251.

ECJ Cases No. C-48/13, Nordea Bank, 17 July 2014.

ECJ Joined Cases No. C-419/12 and C-420/12, Crono Service, 13 February 2014.

ECJ, Case No. C-357/10, Duomo Gpa, 10 May 2012.

Eijsden A., Dam J., The Impact of European Law on Domestic Procedural Tax Law: Wrongfully Underestimated?, „EC Tax Review”, Vol. 19, No. 5/2010.

English J., Taxation of Cross-Border Dividends and EC Fundamental Freedoms, „Inter-tax", Vol. 38, No. 4/ 2010.

Explanatory memorandum of the Polish Government to the Draft Bill of September 17 2013.

Genta G., Dividends Received by Investment Funds: An EU Law Perspective - Part 2, „European Taxation”, Vol. 53, No. 4/2013.

Golec S., Opodatkowanie podatkiem dochodowym akcjonariuszy spótek komandytowo-akcyjnych - zagadnienia problemowe, „Przegląd Podatkowy”, No. 6/2012.

Hemels S., Rompen J., Smet P., De Waele I., Adfeldt S., Breuninger G., Ernst M., Car-pentier V., Mostafavi S., Freedom of Establishment or Free Movement of Capital: Is There an Order of Priority? Conflicting Visions of National Courts and the ECJ, „EC Tax Review“, Vol. 19, No. 1/2010.

Hurk H., Wagenaar B., The Far-Reaching Consequences of the ECJ Decision in Bosal and the Response of the Netherlands, „BIFD “, Vol. 58, No. 6/2004.

Jamroży M., Spótka komandytowo-akcyjna jako podatkowy webikut inwestycyjny, [in:] R. Bartkowiak, J. Ostaszewski (ed.), Dorobek ekonomii, finansów i nauk o zarzqdzaniu oraz jego praktyczne wykorzystanie na przetomie XX i XXI wieku, Szkoła Główna Handlowa - Oficyna Wydawnicza, Warszawa 2012.

Kaldellis E., Freedom of Establishment versus Freedom to Provide Services: An Evaluation of Case-law Developments in the Areas of Indistinctly Applicable Rules, „Legal Issues of Economic Integration“, Vol. 1/2001.

Kopec A., Nagel A., Polnische KGaA als steuerliches Gestaltungsinstrument deutscher Investoren: Von Irrungen und Wirrungen und der Zukunft eines Investitionsvehikels, „IStR“, No. 24/2013. 
Kudert S., Kopec A., Die Besteuerung der polnischen KGaA im Lichte der Steuerreform 2014: Gesetzesziele, Vorgehensweise und Regelungsdefizite, „RIW”, Vol. 5/2014.

Kudert S., Kopec A., Nagel A., Poland: 2014 Income Tax Law Changes: New Taxation Rules for Partnerships Limited by Shares, „European Taxation”, Vol. 55, No. 1/2015.

Neyt R., Neeters S., Balanced Allocation and Coherence: Some Thoughts in Light of Argenta and $K$, „EC Tax Review”, Vol. 23, No. 2/2014.

O'Shea T., Tax avoidance and abuse of EU Law, „EC Tax Journal”, Vol. 11/2010.

Oberrath J., Vereinbarkeit deutscher Steuervorschriften mit Gemeinschaftsrecht, "JA“ Vol. 2006.

OECD, Model Tax Convention on Income and on Capital 2010, http://dx.doi. org/10.1787/9789264175181-en.

Panayi C., The Schempp case: a new leaf in the jurisprudence of the Court of Justice or just a fig leaf?, „European Taxation“, Vol. 45, No. 11/2005.

Pankiewicz P., Ambiguous income tax regulation reveals preferential tax regime in Poland, „European Taxation”, Vol. 53, No. 1/2013.

Stiller W., How to tax partnerships limited by shares, „Journal of Economics \& Management", Vol. 18/2014.

Treaty on the Functioning of the European Union of October 26, 2012, Dz.U. C 326.

Tryfonidou A., Reverse discrimination in purely internal situations: an incongruity in a citizens' Europe, „Legal Issue of Economic Integration”, Vol. 35, No. 1/2008.

Ustawa z dnia 8 listopada 2013 r. o zmianie ustawy o podatku dochodowym od osób prawnych, ustawy o podatku dochodowym od osób fizycznych oraz ustawy o podatku tonażowym (Corporate Income Tax and Personal Income Tax Ammendent Act of November 8, 2013), Dz.U., No. 8, item 1387.

Vanistendael F., Cohesion: The phoenix rises from the ashes, „EC Tax Review”, Vol. 4/2005.

Wołowiec T., Soboń J., EU Integration and Harmonisation of Personal Income Taxation, „Contemporary Economics”, Vol. 5, No. 1/2011, http://dx.doi.org/10.5709/ ce.1897-9254.3. 
